Canadian Journal of Plant Science Revue canadienne de phytotechnie

\title{
Prohexadione-Ca and Ethephon Suppress Shoot Growth of Sweet Cherries (P. Avium)
}

\begin{tabular}{|c|c|}
\hline Journal: & Canadian Journal of Plant Science \\
\hline Manuscript ID & CJPS-2016-0271.R2 \\
\hline Manuscript Type: & Article \\
\hline Date Submitted by the Author: & 14-Dec-2016 \\
\hline Complete List of Authors: & $\begin{array}{l}\text { Cline, John; University of Guelph Ontario Agricultural College, Plant } \\
\text { Agriculture }\end{array}$ \\
\hline Keywords: & $\begin{array}{l}\text { Plant growth regulators, bioregulators, Apogee } \AA \text {, Ethrel } \AA \text {, vegetative } \\
\text { growth, Prunus avium L. }\end{array}$ \\
\hline
\end{tabular}

SCHOLARONE ${ }^{\text {IM }}$

Manuscripts 


\title{
Prohexadione-Ca and Ethephon Suppress Shoot Growth of Sweet Cherries ( $P$. avium)
}

John A. Cline

Department of Plant Agriculture, Ontario Agricultural College, University of Guelph, Simcoe, Ontario, Canada N3Y 4N5. Corresponding author (e-mail: john.cline@uoguelph.ca)

\begin{abstract}
A three year orchard study was conducted on 'Tehranivee' an advanced selections of sweet cherry on Mazzard and Gisela 6 rootstocks to determine the efficacy of different prohexadione-calcium (PC) and ethephon (ETH) treatments on vegetative growth. In one experiment, cherry trees were treated with 123 or $246 \mathrm{mg} \mathrm{L}^{-1} \mathrm{PC}$ and sprayed on 16 and 30 days after full bloom (DAFB) or 16,30 , and 44 DAFB. In a second and third experiment trees were treated pre-bloom (-6 DAFB) and post bloom with PC at 7 and 24 DAFB and rates similar to experiment 1 , as well as with tank-mix sprays of 123 to 246 $\mathrm{mg} \mathrm{L}^{-1} \mathrm{PC}$ and $175 \mathrm{mg} \mathrm{L}^{-1} \mathrm{ETH}$ applied at various timings. $\mathrm{PC}$ alone or in combination with ETH decreased the vegetative shoot growth by up to $74 \%$ compared with the untreated control, but this varied by cultivar and year, as well as PGR application rate, frequency and timing. Lower rates of $\mathrm{PC}$ at $123 \mathrm{mg} \mathrm{L}^{-1}$ were as effective as $246 \mathrm{mg} \mathrm{L}^{-1}$. No benefit was observed in applying PC pre-bloom before active shoot growth had begun.
\end{abstract}

Key Words: Plant growth regulators, bioregulators, Apogee $₫$, Ethrel $₫$, vegetative growth, Prunus avium L. 
Abbreviations: PGR, plant growth regulator; GA, gibberellin; PC, prohexadionecalcium; ETH, ethrel; AMS, ammonium sulfate; TCSA, trunk cross-sectional area; DAFB, days after full bloom

The inherent vigor, lack of precocity, and continued wide use of vigorous rootstocks such as Mazzard for sweet cherry trees (Prunus avium L.) are the impetus for developing orchard management strategies that shift favour reproductive over vegetative growth and promote early and abundant fruit production. In an effort to improve the production of sweet cherries, several high-density training systems that rely on precocious dwarfing or semi-dwarfing clonal rootstocks have been developed (Robinson 2005). Unfortunately, issues such as poor vigour, lack of winter hardiness, susceptibility to spring frost, decreased fruit size, and early over-cropping have been associated with the use of some clonal rootstocks in North America (Perry et al. 1996; Lang 2000; Robinson 2005; Long and Kaiser 2010). The clonal semi-dwarfing rootstock 'Gisela 6' from the German Gisela Series (P. cerasus $\times$ P. canescens) has shown promise in Canada and the United States, particularly with respect to precocity and fruit production. Despite its potential beneficial attributes, 'Gisela 6' is notably prone to early over-cropping. Sweet cherry cultivars on Gisela 6 rootstock therefore require early pruning, followed by more aggressive pruning once trees mature in order to manage the tree canopy and maintain fruit size and quality (Andersen et al. 1999; Whiting et al. 2005; Long \& Kaiser 2010). While ongoing research continues to uncover new information about size-controlling rootstocks, the standard seedling rootstock 'Mazzard' (P. avium L.) remains the most commonly used rootstock for sweet cherries grown commercially in Southern Ontario. Although it is reliable and demonstrates a high level 
of compatibility with a majority of cherry cultivars, Mazzard is slow to bear and produces strong vegetative growth (OMAFRA 2009).

Given the current lack of consensus on the most suitable precocious dwarfing sweet cherry rootstocks to use and consequent use of Mazzard as the rootstock of choice in Ontario and British Columbia, a practical solution to control tree vigour, shoot growth, encourage precocity, and improve fruit quality is desired. Vegetative growth control of fruit trees is typically accomplished by the physical means of pruning and training, which is a costly, time-consuming, and labour-intensive practice (Webster 1998; Rademacher 2004; Robinson 2005). As a result, considerable research has been conducted with fruit trees, including sweet cherries, to explore the feasibility of using PGRs to control shoot growth as well as affect flower initiation and fruit set. The gibberellin -synthesis inhibitors daminozide and paclobutrazol have demonstrated effective control of vigorous sweet cherry shoot growth (Facteau and Rowe 1979; Facteau and Chestnut 1991); however, they are not commercially available for use on fruit trees in Canada and several other countries due to concerns over environmental persistence and residues in fruit (Rademacher 2004; Cares et al. 2014).

Prohexadione-calcium (PC; trade name Apogee $®$; BASF Canada Inc., Mississauga, $\mathrm{ON}$ ) is a GA-synthesis inhibitor that has also been used to control excessive vegetative growth in fruit trees, notably apple (Byers et al. 2004; Cline 2005; Duyvelshoff and Cline 2013), pear (Sugar et al. 2004; Einhorn et al. 2014), and sweet cherry (Guak et al. 2005; Jacyna and Lipa 2010). Results from these studies indicate that the efficacy of PC in reducing shoot elongation varies according to several factors, including climatic conditions, application timing, rate, and frequency, as well as crop and cultivar 
response. In order to reach the shoots of fruit trees, PC is applied as a foliar spray. Upon entering plant cells, it is translocated acropetally through the xylem where it inhibits the biosynthesis of active GA isomers, thereby initiating a reduction in shoot elongation. Unlike daminozide and paclobutrazol, PC displays very safe toxicological and ecotoxicological properties (Evans et al. 1999; Rademacher et al. 2006). Previous research has shown that in sweet cherry, the efficacy of PC in controlling vegetative growth is improved when it is combined with ethephon $(\mathrm{ETH}$; trade name Ethrel$囚$, Bayer CropScience Inc., Calgary, AB), which releases the senescence and ripening plant hormone ethylene (Elfving et al., 2003; 2004; 2005).

The objectives of this research were to determine the efficacy of different PC and ETH treatments on the vegetative growth of sweet cherry cultivars grown on Mazzard and Gisela 6 rootstocks in Southern Ontario.

\section{MATERIALS AND METHODS}

A research orchard of 'Tehranivee'/Gisela 6 (Gi.6), 'Tehranivee'/Mazzard, 'V690628'/G.6, and 'V84071'/Mazzard rootstock located at the University of Guelph, Vineland Campus ( $43^{\circ} 10.800^{\prime} \mathrm{N}$ Lat, $79^{\circ} 24.000^{\prime} \mathrm{W}$ Long, elevation $79.20 \mathrm{~m}$ ) planted in 2002 within a one-meter herbicide strip at a spacing of $2.5 \mathrm{~m} \times 4.0 \mathrm{~m}(1,000$ trees ha ${ }^{-1}$ ) was used for this study. The soil consisted of a Vineland fine sandy loam soil and trees were trickle irrigated and trained to a 'Vogel' central leader training system (Long, 2001) with a $2 \mathrm{~m}$ wooden support post adjacent to each tree. Standard cultural and pest management practices for Ontario were used (Anonymous, 2008). Weed and grass vegetation within the herbicide strip was controlled by spraying $1 \%(\mathrm{v} / \mathrm{v})$ glyphosate in 
mid- May, June, and July each year. A permanent sod culture was established between rows in 2003 using a mixture of creeping red fescue, tall fescue, and perennial ryegrass (Vineland Growers, Vineland, ON). Prior to this study, all trees were managed uniformly and were not subjected to any experimental treatments. Additionally, different trees were used in each of the following experiments.

All experiments used single-tree plots in randomized complete-block designs. Treatments were applied using a commercial air blast sprayer (GB Irrorazione Diserbo, Model Laser P7, Italy) to both sides of the single-tree plots at $1379 \mathrm{kPa}, 3,000 \mathrm{~L} \mathrm{ha}^{-1}$. A disc-core type hollow cone spray tip (Tee-Jet, Wheaton, Illinois) was used and the sprayer was calibrated to spray equally from five nozzles on each side of the sprayer. To minimize treatment interference caused by spray drift, experimental units were separated by at least one guard tree where possible.

\section{Experiment 1 (2008)}

Seven-yr-old 'Tehranivee' trees were treated with one of the following 7 treatments: 1 ) untreated (water control); 2) $123 \mathrm{mg} \mathrm{L}^{-1}$ (370 g ha ${ }^{-1}$ ) PC on May 26; 3) $123 \mathrm{mg} \mathrm{L}^{-1} \mathrm{PC}$ on May 26 and June 9; 4) $123 \mathrm{mg} \mathrm{L}^{-1} \mathrm{PC}$ on May 26, June 9, and June 23; 5) $246 \mathrm{mg} \mathrm{L}^{-1}$ $\left(740 \mathrm{~g} \mathrm{ha}^{-1}\right) \mathrm{PC}$ on May 26; 6) $246 \mathrm{mg} \mathrm{L}^{-1} \mathrm{PC}$ on May 26 and June 9; or 7) $246 \mathrm{mg} \mathrm{L}^{-1}$ PC on May 26, June 9, and June 23. Treatments were replicated ten times. All sprays

included $0.05 \%(\mathrm{v} / \mathrm{v})$ Agral 90 surfactant (Syngenta Crop Protection Canada Inc., Guelph, ON) and ammonium sulfate (AMS) equivalent to the rate of PC. The length of new growth (current season) on up to 17 extension shoots (unheaded and selected randomly on each date) as well as the primary leader were measured on May 29, June 10, June 24, July 14, August 6, and August 18. Trees were in full bloom on May 10. The 
terminal buds had set on the last measuring data indicating the cessation of growth. The average extension and leader shoot length during the first application (May 26) was $\approx 12.9$ and $12.7 \mathrm{~cm}$, respectively. Tree trunk circumference was measured $30 \mathrm{~cm}$ above the soil line at the end of the growing season to calculate trunk cross-sectional area (TCSA). No return bloom or yield data were collected in this experiment.

\section{Experiment 2 (2009)}

Eight-yr-old 'V690628'/G.6 trees (six replications per treatment) and 'V84071'/Mazzard trees (four replications per treatment) were treated pre-bloom (May 2), early (May 15), and/or late (June 1) as follows: 1) untreated (water control); 2) $61.5 \mathrm{mg} \mathrm{L}^{-1}\left(185 \mathrm{~g} \mathrm{ha}^{-1}\right.$ ) PC on May 15 and June 1; 3) $123 \mathrm{mg} \mathrm{L}^{-1}\left(370 \mathrm{~g} \mathrm{ha}^{-1}\right) \mathrm{PC}$ on May 15 and June 1; 4) 246 $\mathrm{mg} \mathrm{L}^{-1}\left(740 \mathrm{~g} \mathrm{ha}^{-1}\right) \mathrm{PC}$ on May 15 and June $\left.1 ; 54\right)$ tank-mix of $123 \mathrm{mg} \mathrm{L}^{-1} \mathrm{PC}$ and 175 $\mathrm{mg} \mathrm{L}^{-1}\left(518 \mathrm{~g} \mathrm{ha}^{-1}\right) \mathrm{ETH}$ on May 15, followed by $123 \mathrm{mg} \mathrm{L}^{-1} \mathrm{PC}$ on June $\left.1 ; ; 6\right)$ tank-mix of $246 \mathrm{mg} \mathrm{L}^{-1} \mathrm{PC}$ and $175 \mathrm{mg} \mathrm{L}^{-1} \mathrm{ETH}$ on May 15 , followed by $246 \mathrm{mg} \mathrm{L}^{-1} \mathrm{PC}$ on June 1 ; 7) tank-mix of $246 \mathrm{mg} \mathrm{L}^{-1} \mathrm{PC}$ and $175 \mathrm{mg} \mathrm{L}^{-1} \mathrm{ETH}$ on May 15 and June 1 ; 8) $123 \mathrm{mg} \mathrm{L}^{-1}$ PC on May 2, May 15, and June 1; or 9) $123 \mathrm{mg} \mathrm{L}^{-1} \mathrm{PC}$ on May 2, followed by tank-mix of $123 \mathrm{mg} \mathrm{L}^{-1} \mathrm{PC}$ and $175 \mathrm{mg} \mathrm{L}^{-1} \mathrm{ETH}$ on May 15. For all treatments, Agral and AMS were added at the same concentration as described in Experiment 1.

For each tree, the length of new growth on extension shoots (two to five selected randomly on each date) and the primary leader shoot were measured on May 19, May 26, June 2, June 16, July 6, July 27, and August 17 . Trees were in full bloom on May 8. The terminal buds had set by the last measurement date, indicating the cessation of growth for the season. The average extension and leader shoot length during the early application (May 15) were $\approx 2.4$ and $2.0 \mathrm{~cm}$, respectively for 'V690628'/G.6 trees and 
$\approx 4.3$ and $2.5 \mathrm{~cm}$, respectively for 'V84071'/Mazzard trees. Tree trunk circumference was measured as in Experiment 1. Leaf phytotoxicity was determined on May 25, June 12, and June 26, and fruit phytotoxicity was determined on July 15 using a rating scale of 0 $100 \%$. On May 11, a spring frost at bloom resulted in a complete crop loss of 'V84071' and a substantial crop loss of 'V690628'. This effect was not observed until late May after fruit failed to set, but after PC applications had been made. As a result, accurate determination of treatment effects on yield, marketable fruit, and fruit quality were not possible for this experiment. In the spring of 2010, for both 'V690628' and 'V84071', the number of gummosis sites was counted and return bloom was measured on each tree using a rating scale of 1-5 (where 1=no bloom, 2=moderate bloom, 3=moderate bloom, 4=high amount of bloom, 5=very high amount of bloom).

\section{Experiment 3 (2011)}

Ten-yr-old 'V690628'/G.6 trees (six replications per treatment) were treated pre-bloom (May 12), early (May 21), and/or late (June 4) as follows: 1) untreated (water control); 2) $61.5 \mathrm{mg} \mathrm{L}^{-1} \mathrm{PC}$ on May 15 and June 4; 3) $123 \mathrm{mg} \mathrm{L}^{-1} \mathrm{PC}$, applied May 21 and June 4; 4) $246 \mathrm{mg} \mathrm{L}^{-1} \mathrm{PC}$, applied May 21 and June 4; 54) tank-mix of $123 \mathrm{mg} \mathrm{L}^{-1} \mathrm{PC}$ and $175 \mathrm{mg}$ $\mathrm{L}^{-1} \mathrm{ETH}$, applied May 21, plus $123 \mathrm{mg} \mathrm{L}^{-1} \mathrm{PC}$, applied June 4;; 6) tank-mix of $246 \mathrm{mg} \mathrm{L}^{-1}$ PC and $175 \mathrm{mg} \mathrm{L}^{-1} \mathrm{ETH}$, applied May 21, plus $246 \mathrm{mg} \mathrm{L}^{-1} \mathrm{PC}$, applied June 4; 7) tankmix of $246 \mathrm{mg} \mathrm{L}^{-1} \mathrm{PC}$ and $175 \mathrm{mg} \mathrm{L}^{-1} \mathrm{ETH}$, applied May 21 and June 4; 8) $123 \mathrm{mg} \mathrm{L}^{-1}$ PC, applied May 12, May 21, and June 4; or 9) $123 \mathrm{mg} \mathrm{L}^{-1} \mathrm{PC}$, applied May 12, plus tank-mix of $123 \mathrm{mg} \mathrm{L}^{-1} \mathrm{PC}$ and $175 \mathrm{mg} \mathrm{L}^{-1} \mathrm{ETH}$, applied May 21. For all treatments, Agral and AMS were added as in Experiment 1 and 2. 
For each tree, the length of new growth on extension shoots (two to five selected randomly on each date) were measured on May 24 , June 5 , June 15 , July 3 , July 17 , and August 11, by which time terminal buds had set. The average extension shoot length during the early application (May 21 ) was $\approx 1.4 \mathrm{~cm}$. Trees were in full bloom on May 11. Tree trunk circumference was measured as in Experiment 1. Following rain and warm weather, a high incidence of fruit became infected by brown rot (Monilinia fructicola), which caused substantial crop damage. Therefore, the determination of treatment effects on yield, marketable fruit, and fruit quality were not possible.

\section{Data analyses}

Data from all experiments were subjected to analysis of variance using the PROC GLM procedure of SAS (SAS Institute, Cary, NC). Duncan's Multiple Range Test was used to separate treatment means $(P=0.05)$. Means of non-transformed data are reported in figures. Single degree of freedom orthogonal comparisons were performed to evaluate specific treatment effects.

\section{RESULTS}

\section{Experiment 1 (2008)}

Periodical measurements of shoots revealed that consistently with each treatment, the primary leader shoots of 'Tehranivee' sweet cherry trees maintained a relatively linear pattern of growth for the entire season (Figure 1a), while extension shoot growth occurred between late May and mid-July then ceased for the remainder of the season

(Figure $1 \mathrm{~b}$ ). A single spray of $\mathrm{PC}$ at a rate of 123 or $246 \mathrm{mg} \mathrm{L}^{-1}$ had only minimal effects 
on reducing leader and extension shoot growth. Multiple applications of PC caused a reduction in the growth of both leader and extension shoots; however, no differences were detected by contrast test between two or three applications of PC or between rates of 123 or $246 \mathrm{mg} \mathrm{L}^{-1}$. When multiple sprays of PC were applied at either rate, significant reductions in both leader and extension shoot length became apparent on June 24 ( $\approx 4$ weeks after the first application), at which time $\approx 1 / 3$ to $2 / 3$ of annual shoot growth had occurred in the control trees. When compared to the control, leader shoot growth was reduced by $\approx 27.9 \%$ on July 14 ; however, following a period of $\approx 6$ weeks, growth control of the treated leader shoots was decreased to $\approx 17.4 \%$ and by terminal bud set, there were no differences between the length of treated and untreated leader shoots. The growth of extension shoots was reduced by $\approx 31.7 \%$ on July 14 , after which it was maintained at $\approx 23.3 \%$ until terminal bud set. Tree growth, as represented by trunk cross-sectional area (TCSA), as well as crop density were unaffected by the treatments $(P=0.2374$ and $P=0.9382$ respectively; data not shown).

\section{Experiment 2 (2009)}

Overall, the seasonal growth response of V690628 and V690628/G.6 sweet cherry primary leader and extension shoots to each treatment was very similar, although the length of leader shoots was consistently about twice the mean extension shoot length, regardless of treatment (data not shown). While two applications of PC alone at rates of 61.5 or $123 \mathrm{mg} \mathrm{L}^{-1}$ had transient effects or minimal to no impact on shoot growth reduction, two applications of PC alone at a rate of $246 \mathrm{mg} \mathrm{L}^{-1}$ provided shoot growth control beginning $\approx 6$ weeks after the early PC application (June 26 ), at which time $\approx 1 / 3$ to $1 / 2$ of annual shoot growth had occurred in the control trees (Figure 2a). Compared 
to the control, the length of shoots sprayed twice with $246 \mathrm{mg} \mathrm{L}^{-1}$ was reduced by as much as $53.4 \%$ during the growing season. By terminal bud set, they were $47.9 \%$ shorter than untreated shoots.

When compared to the control or to PC alone, all treatments that included ETH provided earlier and an overall greater magnitude of shoot growth control over the course of the season (Figure 3a), albeit non-significantly. For all treatments that included ETH, shoot growth control became noticeable $\approx 1.5$ weeks following the early PC application (May 26), by which time less than $1 / 6$ of annual shoot growth had occurred in the untreated trees. The combination of ETH with 2 applications of PC at $123 \mathrm{mg} \mathrm{L}^{-1}$ (either applied pre-bloom and early, or early and late) provided as much as 46.7-62.6\% growth reduction until late July, after which the persistence of this control began to cease. By terminal bud set, shoots treated with ETH and 2 applications of 123 $\mathrm{mg} \mathrm{L}^{-1} \mathrm{PC}$ were only 3.5 to $8.0 \%$ shorter than untreated shoots. During the growing season, two applications of $P C$ at $246 \mathrm{mg} \mathrm{L}^{-1}$ reduced shoot growth by as much as $66.4 \%$ when combined with a single ETH application or $73.6 \%$ when combined with a double ETH application. By terminal bud set, these shoots were $27.1 \%$ shorter when ETH was applied once, and $57.2 \%$ shorter when ETH was applied twice.

According to the contrast tests, pre-bloom PC applications were not effective in reducing shoot growth. The combination of ETH and PC reduced both leader and extension shoot growth for $\approx 4$ weeks (May 26 to June 26) while shoot growth was reduced for $\approx 4$ weeks (June 26 to July 27 ) proportional to the concentration of PC.

The number of lateral shoots (May 15 and July 15) and TCSA were unaffected by the treatments $(P=0.3108, P=0.4852$, and $P=0.2917$ respectively; data not shown). 
Visual ratings suggest that leaves (May 29, June 12, and June 29) and fruit (July 15) were unaffected by phytotoxicity. Since measurements were between 0 and $5 \%$ on all occasions and were similar for all treatments, statistical analyses of these data were not possible. It was concluded that neither PC nor any of the components in the spray resulted in phytotoxic effects on leaves or fruit. Additionally, return bloom and gummosis ratings done in spring 2010 were unaffected by the treatments (data not shown).

\section{Experiment 2 ('V84071'/Mazzard)}

When PC was applied alone at rates of 61.5 or $123 \mathrm{mg} \mathrm{L}^{-1}$, leader and extension shoots of V84071 sweet cherry trees had responses similar to those of V690628 by showing minimal to no shoot growth reduction (Figure $2 \mathrm{~b}$ ). When the abovementioned treatments were applied, the length of leader shoots was about 1.5 times the mean extension shoot length (data not shown). In comparison to V690628 trees, the treatment of two applications of $246 \mathrm{mg} \mathrm{L}^{-1} \mathrm{PC}$ alone was substantially less effective at reducing shoot growth in V84071. Although V84071 shoots responded to the treatment two weeks earlier than V690628 shoots, by terminal bud set, they were $16.7 \%$ shorter than untreated shoots.

Treatments that included ETH had the earliest effect on reducing V84071 shoot length, when $\approx 1 / 4$ of annual shoot growth had occurred in the control trees. However, these effects became noticeable one week later than was observed with V690628 shoots (Figure 3b). For all treatments that included ETH (with the exception of the treatment that included pre-bloom PC), the growth reduction response of primary leaders was substantially greater than the response of extension shoots, with up to an $82.0-84.3 \%$ reduction of leader growth, compared to a $56.8-68.8 \%$ reduction of 
extension shoots during the season (data not shown). When a single application of ETH was combined with a single application of either $123 \mathrm{mg} \mathrm{L}^{-1}$ or $246 \mathrm{mg} \mathrm{L}^{-1} \mathrm{PC}$, leader shoots were $70.7 \%$ or $40.6 \%$ shorter, respectively at terminal bud set when compared to untreated shoots, while extension shoots were $3.0 \%$ or $5.6 \%$ shorter, respectively. When ETH was applied twice in combination with two applications of PC at $246 \mathrm{mg} \mathrm{L}^{-1}$ PC, leader shoot growth was reduced by $70.4 \%$ at terminal bud set, while extension shoot growth was reduced by $36.8 \%$. Thus, multiple applications of ETH did not improve the level of growth control achieved with just one ETH application.

According to the contrast tests, the effects of pre-bloom PC applications did not reduce shoot growth (data not shown). The combination of ETH and PC reduced both the primary leader and extension shoot growth for $\approx 4$ weeks (June 2 to July 6 for primary leader shoots; May 26 to June 26 for extension shoots). While PC alone had no effect on reducing primary leader shoot growth, extension shoot growth decreased proportionally to concentration for $\approx 3$ weeks (June 16 to July 6 ).

Neither the number of lateral shoots (May 15 and July 15) nor TCSA were affected by the treatments $(P=0.6420, P=0.7662$, and $P=0.0909$ respectively; data not shown). Additionally, visual ratings suggest that leaves (May 29, June 12, and June 29) and fruit (July 15) were unaffected by phytotoxicity, and return bloom and gummosis ratings made in spring 2010 were unaffected by the treatments.

\section{Experiment 3 ('V690628'/G.6)}

As observed in 2009, two sprays of PC at $61.5 \mathrm{mg} \mathrm{L}^{-1}$ had minimal to no effect on reducing extension shoot length of V690628 sweet cherry trees during the growing season, when compared to the control (Figure 4a). Overall, the shoot growth response 
with all other treatments was immediate following the early application of PC, regardless of whether it was applied alone or in combination with ETH, and persisted until terminal bud set.

The growth response of shoots treated with $123 \mathrm{mg} \mathrm{L}^{-1}$ of PC alone (either with or without pre-bloom PC) as well as with $246 \mathrm{mg} \mathrm{L}^{-1}$ of $\mathrm{PC}$ alone remained very similar until July 3. At this point, shoots that received the above treatments were $\approx 57.8 \%$ shorter than the control. After July 3 , the growth of shoots treated with $123 \mathrm{mg} \mathrm{L}^{-1}$ of PC alone without pre-bloom PC ceased and was maintained at $\approx 55.5 \%$ until terminal bud set, while the growth of shoots treated with $123 \mathrm{mg} \mathrm{L}^{-1}$ of $\mathrm{PC}$ alone with pre-bloom PC or with $246 \mathrm{mg} \mathrm{L}^{-1}$ of PC continued slightly for an additional two weeks. By terminal bud set, they were $\approx 38.8 \%$ shorter than the control.

During the growing season, the elongation of shoots treated with $123 \mathrm{mg} \mathrm{L}^{-1}$ of PC with ETH (either pre-bloom and early, or early and late) was very similar to shoots treated with $123 \mathrm{mg} \mathrm{L}^{-1}$ of PC plus pre-bloom PC (Figure 4b). Between June 15 and July 17, treatments of $\mathrm{PC}$ at $246 \mathrm{mg} \mathrm{L}^{-1}$ combined with either one or two applications of ETH provided an additional $46.3 \%$ reduction in growth when compared to $123 \mathrm{mg} \mathrm{L}^{-1}$ of PC with ETH. Despite this, by terminal bud set, all treatments that included ETH were similarly $\approx 42.4 \%$ shorter than the control.

According to the contrast tests, PC alone reduced extension of shoot growth proportional to concentration from May 24 until terminal bud set. The combination of PC with ETH reduced shoot extension for $\approx 4$ weeks (June 5 to July 3 ) while pre-bloom PC reduced shoot extension for 10 days (June 5 to June 15). TCSA was unaffected by the treatments $(P=0.1971$; data not shown $)$. 


\section{DISCUSSION}

This study indicates that under Southern Ontario climatic conditions, PC can markedly decrease the vegetative shoot growth of sweet cherry trees on rootstocks that promote medium-high to high vigor. This is consistent with the results of past experiments conducted in Summerland, BC (Guak et al. 2005), Poland (Jacyna and Lipa 2010, Jacyna et al. 2012), Chile (Cares et al. 2014), and the Pacific Northwest, USA (Elfving et al. 2003; 2004; 2005).

Overall, the results from this study fail to demonstrate consistent benefits of using $\mathrm{PC}$ alone at higher rates of $246 \mathrm{mg} \mathrm{L}^{-1}$ compared to lower rates of $123 \mathrm{mg} \mathrm{L}^{-1}$ on reduced shoot growth. The inconsistencies in the growth responses of V690628 shoots to PC in 2009 and 2011 as well as the differences observed between the V890628 and V84071 cultivars when treated with equal rates of PC are supported by the findings of Elfving et al. $(2003 ; 2004 ; 2005)$ on several sweet cherry cultivars grown in the Pacific Northwest.

While the shoot growth response of 'Tehranivee' trees to PC was variable in relation to application frequency, it was unaffected by the rate of application (123 or $246 \mathrm{mg} \mathrm{L}^{-1}$ ). A single spray of PC to 'Tehranivee' extension shoots had no impact on their growth; however, one or two additional sprays applied at two-week intervals both had similar season-long reducing effects, regardless of whether 123 or $246 \mathrm{mg} \mathrm{L}^{-1}$ of $\mathrm{PC}$ was used (Figure 1b). In accordance with this, previous studies reporting on vegetative growth control in sweet cherry have demonstrated that repeat applications of PC at $246 \mathrm{mg} \mathrm{L}^{-1}$ spaced two weeks apart can provide season-long inhibition of shoot growth (Guak et al. 2005; Cares et al. 2014). Contrary to observations made in the current study, Cares 
et al. (2014) demonstrated that a single application of $P C$ at a rate of $246 \mathrm{mg} \mathrm{L}^{-1}$ was sufficient to provide season-long shoot growth reduction similar to that observed with the two applications of PC. However, Guak et al. (2005) observed that repeat applications of $123 \mathrm{mg} \mathrm{L}^{-1} \mathrm{PC}$ were insufficient in reducing shoot growth when compared to the control. These results, combined with observations made by Elfving et al. $(2003 ; 2004)$, suggest that the response of shoots to PC varies according to growth stage at the time when PC is applied. In addition, tree cultivar, age, weather conditions, and orchard location also appear to be factors in shoot response to PC. Further research is needed to fully understand and quantify these factors, particularly the seasonal effects of weather (for example, temperature, sunlight) in the humid continental climate of southern Ontario and how this affects plant growth and development.

In a few instances, it was apparent that early shoot growth regulation from PC was lost by the end of the season. A repeat application of PC at approximately 60 DAFB when growth typically continues past this period, in most cases would be warranted if season-long growth regulation is desired.

While trees are young and non-bearing, greater shoot growth during the establishment years is desirable - usually the year of and the year following planting. Thereafter, growth control in favour of fruiting is desirable during the transition years until the trees are mature. Once trees are mature and have filled their allotted canopy space, vegetative growth control of both the primary leader and extensions shoots is required, combined with strategic annual renewal pruning to encourage the development of new fruiting wood. In size-controlling orchard systems such as the 
'Vogel' central leader, Spanish Bush and upright fruiting offshoot system (UFO, Whiting, 2008), the horticultural objective is to produce high quality fruit early during the transition years and establish the tree architecture with concomitantly controlling growth. Limiting vegetative growth of extension shoots using combination sprays of $\mathrm{PC}$ and $\mathrm{ETH}$ or PC alone, which resulted in $20-50 \%$ reduction in shoot length, is unlikely to interfere with the desired balance of vegetative and fruiting required during the transition years. Prohexidione-calcium reduces shoot internode length without affecting the number of leaves per shoot (Jacyna and Lipa 2010, Evans et al. 1997), and therefore it is unlikely to negatively influence the leaf area:fruit ratio, which markedly influences fruit size (Proebsting, 1990). In experiment two, where growth of the primary (central) leader was inhibited greater than the extension shoots (by as much as $\sim 80 \%$ ), selective spraying of the extension shoots only while avoiding treatment of the primary leader would be preferable during the establishment phase until the tree has reached its desired height. Since it may be impractical in target sprays toward extension shoots only in commercial orchards using air blast delivery systems, lower rates of PC and ETH may be required.

Results from this study also fail to demonstrate any benefits of applying pre-bloom PC to shoots before they begin active growth. In both 2009 and 2011, vegetative shoots that received early and late applications of $P C$ at a rate of $123 \mathrm{mg} \mathrm{L}^{-1}$, showed similar patterns of growth regardless of whether or not they had additionally received pre-bloom PC (Figure 2b). Since PC degrades within a matter of weeks following its application (Evans et al. 1999), there was likely very little or none of the pre-bloom PC remaining in the shoots that received this treatment by the time they began to grow actively. Similar observations have also been made with PC applications made either after harvest 
(Cares et al. 2014) or in the fall (Manríquez et al. 2005). Due to the low persistence of PC, these observations support limiting the application of $P C$ to the period in which shoots are in active growth.

The use of ETH on sweet cherry trees has previously been shown to reduce shoot growth, delay bloom time, increase flowering, and increase cold hardiness of buds and shoots (Elfving et al. 2003; 2004; Guak et al. 2005). As observed by Elfving et al. (2003; 2004; 2005), the combination of PC and ETH in the present study showed a trend towards a greater magnitude of shoot control earlier in the growing season when compared to the effect of PC alone (Figures 2 and 3). Two applications of PC at $246 \mathrm{mg}$ $\mathrm{L}^{-1}$ combined with two applications of ETH provided the most effective shoot elongation control during the growing season for both the V890628 and V84071 cultivars in 2009. In 2011 however, none of the treatments in which PC and ETH were combined provided additional shoot growth reduction when compared to the treatments with PC alone. Once again, these observations suggest that annual weather conditions influence the response of shoots to $\mathrm{PC}$ and/or ETH since environmental factors such as temperature and precipitation at and around the time of PGR application have been recognized to impact plant response (Duyvelshoff and Cline 2013). Ethephon has been an inconsistent thinning agent (Byers 2003; Byers et al. 2003), likely a result of its degradation and subsequent release of ethylene gas being highly temperature dependent (Olien and Bukovac 1982c,1982d), particularly outside the window of 21$32^{\circ} \mathrm{C}$ (Yuan and Carbaugh, 2007). While there is evidence to support that PC, either alone or in combination with ETH, does not affect fruit yield (Elfving et al. 2003; Jacyna \& Lipa 2010), Rademacher (2004) suggested that the quantities of ETH required to 
effectively reduce shoot growth in sweet cherries could be detrimental to fruit production and quality. In the present study, ETH did not have a measureable effect on return bloom, which is consistent with similar treatments made to non-bearing Lapins'/Mazzard rootstock (Elfving et al. 2003). However, in another experiment on 4-yr-old 'Bing'/Mazzard, applications of $125 \mathrm{mg} \mathrm{L}^{-1} \mathrm{PC}$ and $175 \mathrm{mg} \mathrm{L}^{-1} \mathrm{ETH}$ when terminal shoots were $22 \mathrm{~cm}$ long, resulted in greater flower density the following spring on 1-yrold shoots but not fruiting spurs. Possible reasons for a lack of response in increased flowering the year following application to the combined PC and ETH sprays in the present study are: a) the cultivars 'V690628' and 'V84071' are not responsive to ETH; b) that the time of application did not coincide with actual flower bud initiation, or c) the method of rating bloom was insufficient in determining treatment differences.

The greater the number of shoots measured per tree on each measurement date will result in less variation and therefore greater accuracy in testing treatment difference in this response variable - leading to fewer type I errors. In the present study, where trees were in their mature stage, vigor was such that it was not possible to choose consistently more than five actively growing extension shoots per tree. Consequently, this lead to greater variation and less precision in testing treatment differences statistically, a situation to be avoided if at all possible.

In conclusion, the use of PC alone or in combination with ETH suppressed vegetative shoot elongation, although to a varying extent according to cultivar, year, as well as PGR application rate, frequency and timing. Since Mazzard, known to promote high vigor in sweet cherry trees, remains the most commonly-used rootstock in Southern Ontario, the results from this study demonstrate the promising effects of PC 
and ETH treatments, which could become integral in the planning of practical solutions to manage excessive shoot growth in high density orchards. Further research is required to determine potential impacts of these treatments on factors such as return bloom and flower initiation as well as fruit yield and quality, and to optimize treatment plans for specific cultivars and climatic conditions.

\section{Literature Cited}

Andersen, R.L., Robinson, T., and Lang, G.A. 1999. Managing the Gisela cherry rootstocks. New York Fruit Q. 7: 1-4.

Anonymous, 2008. Publication 360, 2008-2009 Guide to Fruit Production. Ministry of Agriculture, Food and Rural Affairs. Queen's Printer of Ontario. 226 p.

Byers, R.E. 2003. Flower and fruit thinning and vegetative: fruiting balance. p. 409-436. In: D.C. Ferree and I.J. Warrington (eds.). CABI Publishing, Wallingford; UK.

Byers, R.E., G. Costa, and G. Vizzotto. 2003. Flower and fruit thinning of peach and other Prunus. Hort. Rev. 28:351-392.

Byers, R.E., Carbaugh, D.H., and Combs, L.D. 2004. Prohexadione-calcium suppression of apple tree shoot growth as affected by spray additives. HortScience 39: 115-119.

Cares, J., Sagredo, K.X., Cooper, T., and Retamales, J. 2014. Effect of prohexadione calcium on vegetative and reproductive development in sweet cherry trees. Acta Hortic. 1058: $357-364$. 
Cline, J.A. 2005. Apogee ${ }^{\circledR}$ - A new plant bioregulator for apples. Ontario Ministry of Agriculture. Agdex 24/211. Queen's Printer for Ontario. [Online]. Available: http://www.omafra.gov.on.ca/english/crops/facts/06-045.htm [20 August, 2016].

Duyvelshoff, C. and Cline, J.A. 2013. Ethephon and prohexadione-calcium influence the flowering, early yield, and vegetative growth of young 'Northern Spy' apple trees. Sci. Hortic. 151: 128-134.

Einhorn, T.C., Pasa, M.S., and Turner J. 2014. 'D'Anjou' pear shoot growth and return bloom, but not fruit size, are reduced by prohexadione-calcium. HortScience 49: 180187.

Elfving, D.C., Lang, G.A., and Visser, D.B. 2003. Prohexadione-Ca and ethephon reduce shoot growth and increase flowering in young, vigorous sweet cherry trees. HortScience 38: 293-298.

Elfving, D.C., Visser, D.B., Whiting, M.D., and Lang, G.A. 2004. Growth and flowering responses of sweet cherry cultivars to prohexadione-calcium and ethephon. Acta Hortic. 636: $75-82$.

Elfving, D.C., Visser, D.B., and Lang, G.A. 2005. Effects of prohexadione-calcium and ethephon on growth and flowering of 'Bing' sweet cherry. Acta Hortic. 667: 439-446.

Evans, J.R., Evans, R.R., Regusci, C.L., and Rademacher, W. 1999. Mode of action, metabolism, and uptake of BAS 125W, prohexadione-calcium. HortScience 34: 12001201. 
Evans, R.R., Reid, E.J., Rademacher, W. 1997. Prohexadione calcium for suppression of vegetative growth of eastern apples. Acta Hortic. 451, 663-666

Facteau, T.J. and Rowe, K.E. 1979. Growth, flowering, and fruit set responses of sweet cherries to daminozide and ethephon. HortScience 14: 234-236.

Facteau, T.J. and Chestnut, N.E. 1991. Growth, flowering, and fruit quality of sweet cherries treated with paclobutrazol. HortScience 26: 276-278.

Guak, S., Beulah, M., and Looney, N.E. 2005. Controlling growth of sweet cherry trees with prohexadione-calcium: Its effect on cropping and fruit quality. Acta Hortic. 667: 433438.

Jacyna, T. and Lipa, T. 2010. Direct and apparent residual effects of prohexadionecalcium applied to young cropping sweet cherry trees. Acta Agrobot. 63: 87-92.

T. Jacyna, J. Barnard and Wielgus, M. 2012 Immediate and residual effects of prohexadione-calcium, with or without ethephon, applied in a low-pH solution on vegetative and reproductive growth in sweet cherry trees (Prunus avium L.), J. Hort. Sci. and Biotech. 87:577-582.

Lang, G.A. 2000. Precocious, dwarfing, and productive - How will new cherry rootstocks impact the sweet cherry industry? HortTechnology 10: 719-725.

Long, L.E., 2001. Cherry training systems: Selection and development. Pacific Northwest Extension Publication. PNW 543.

Long, L.E. and Kaiser, C. 2010. Sweet cherry rootstocks for the Pacific Northwest. Pacific Northwest Extension Publication 619: 1-8. 
Manríquez, D., Defilippi, B., and Retamales, J. 2005. Prohexadione-calcium, a gibberellin biosynthesis inhibitor, can reduce vegetative growth in 'Bing' sweet cherry trees. Acta Hortic. 667: 447-452.

Olien, W.C. and M. J. Bukovac. 1982a. Ethephon-induced gummosis in sour cherry (Prunus cerasus L.). I. Effect on xylem function and shoot water status. Plant Physiol. 70:547-555.

(OMAFRA) Ontario Ministry of Agriculture, Food and Rural Affairs. 2009. Cherry cultivars - Sweet and tart. [Online] Available:

http://www.omafra.gov.on.ca/english/crops/facts/02-037.htm [2016 Apr. 06].

Perry, R., Lang, G., Andersen, R., Anderson, L., Azarenko, A., Facteau, T., Ferree, D., Gaus, A., Kappel, F., Morrison, F., Rom, C., Roper, T., Southwick, S., Tehrani, G., and Walsh, C. 1996. Performance of the NC-140 cherry rootstock Experiments in North America. Compact Fruit Tree 29: 37-56.

Proebsting, E.L., 1990. The interaction between fruit size and yield in sweet cherry. Fruit Varieties Journal, 44:169-172.

Rademacher, W. 2004. Chemical regulation of shoot growth in fruit trees. Acta Hortic. 653: 29-32.

Rademacher, W., Spinelli, F., and Costa, G. 2006. Prohexadione-Ca: Modes of action of a multifunctional plant bioregulator for fruit trees. Acta Hortic. 727: 97-106.

Robinson, T.L. 2005. Developments in high density sweet cherry pruning and training systems around the world. Acta Hortic. 667: 269-272. 
Sugar, D., Elfving, D.C., and Mielke, E.A. 2004. Effects of prohexadione-calcium on fruit size and return bloom in pear. HortScience 39: 1305-1308.

Webster, A.D. 1998. Strategies for controlling the size of sweet cherry trees. Acta Hortic. 468: 229-240.

Whiting, M.D., Lang, G., and Ophardt, D. 2005. Rootstock and training system affect sweet cherry growth, yield, and fruit quality. HortScience 40: 582-586.

Yuan, R.C. and D.H. Carbaugh. 2007. Effects of NAA, AVG, and 1-MCP on ethylene biosynthesis, preharvest fruit drop, fruit maturity, and quality of 'Golden Supreme' and 'Golden Delicious' apples. HortScience 42:101-105. 


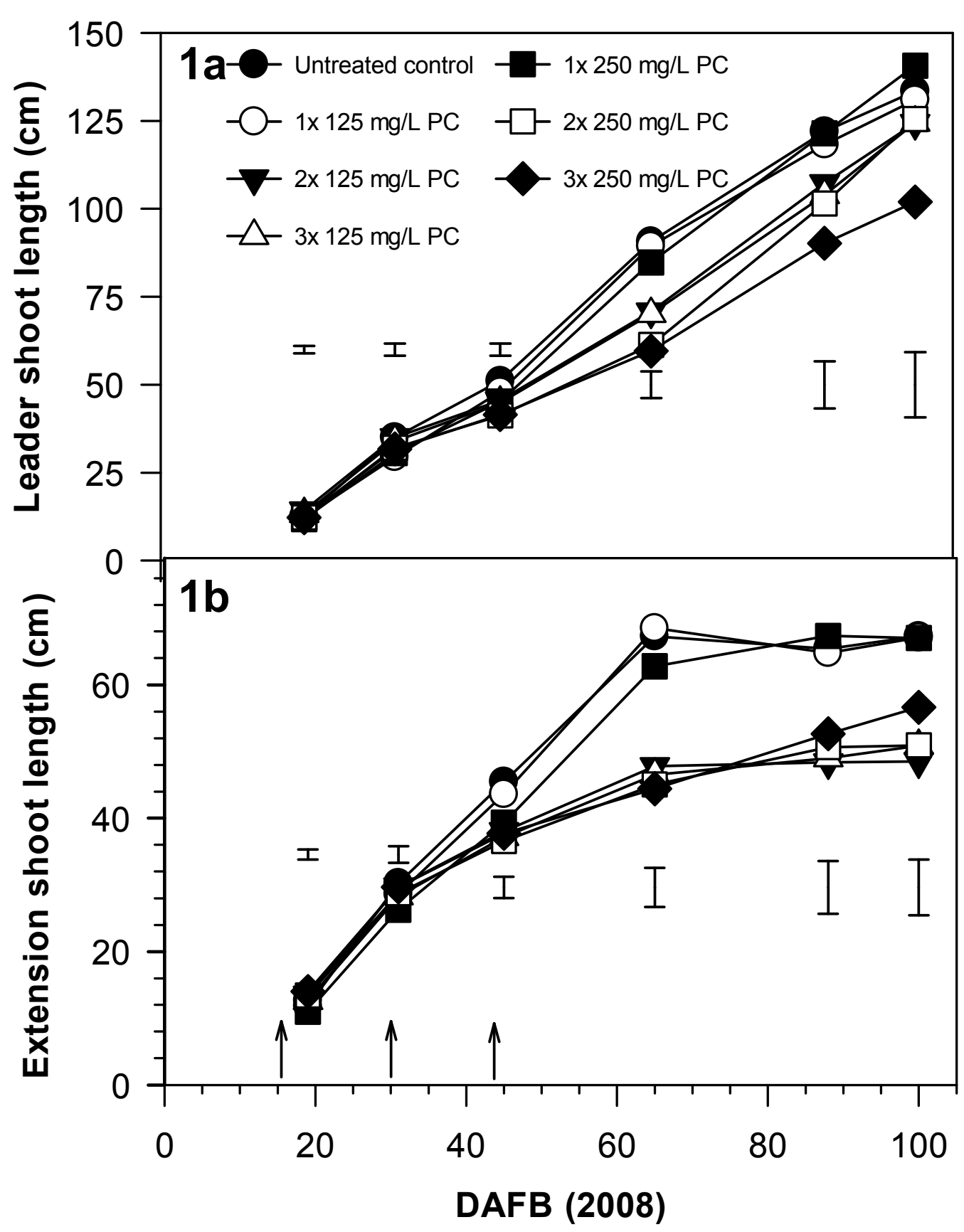

Figure 1. Primary leader (1a) and extension (1b) shoot growth over time as affected by different rates and frequencies of prohexadione-calcium (PC) sprays on 'Tehranivee' sweet cherry trees. Treatments: $(\mathbf{O})$ untreated control, 1 application of $123 \mathrm{mg} \mathrm{L}^{-1}$ $\mathrm{PC}(\mathrm{O}) ; 2$ applications of $123 \mathrm{mg} \mathrm{L}^{-1} \mathrm{PC}(\boldsymbol{\nabla}) ; 3$ applications of $123 \mathrm{mg} \mathrm{L}^{-1} \mathrm{PC}(\Delta) ; 1$ application of $246 \mathrm{mg} \mathrm{L}^{-1} \mathrm{PC}(\boldsymbol{\square}) ; 1$ applications of $246 \mathrm{mg} \mathrm{L}^{-1} \mathrm{PC}(\square) ; 3$ applications of $246 \mathrm{mg} \mathrm{L}^{-1} \mathrm{PC}()_{)}$. All data are expressed as means and error bars represent the standard error of the means. Arrows indicate the application dates of PC (May 26, June 9 , and June 23). 


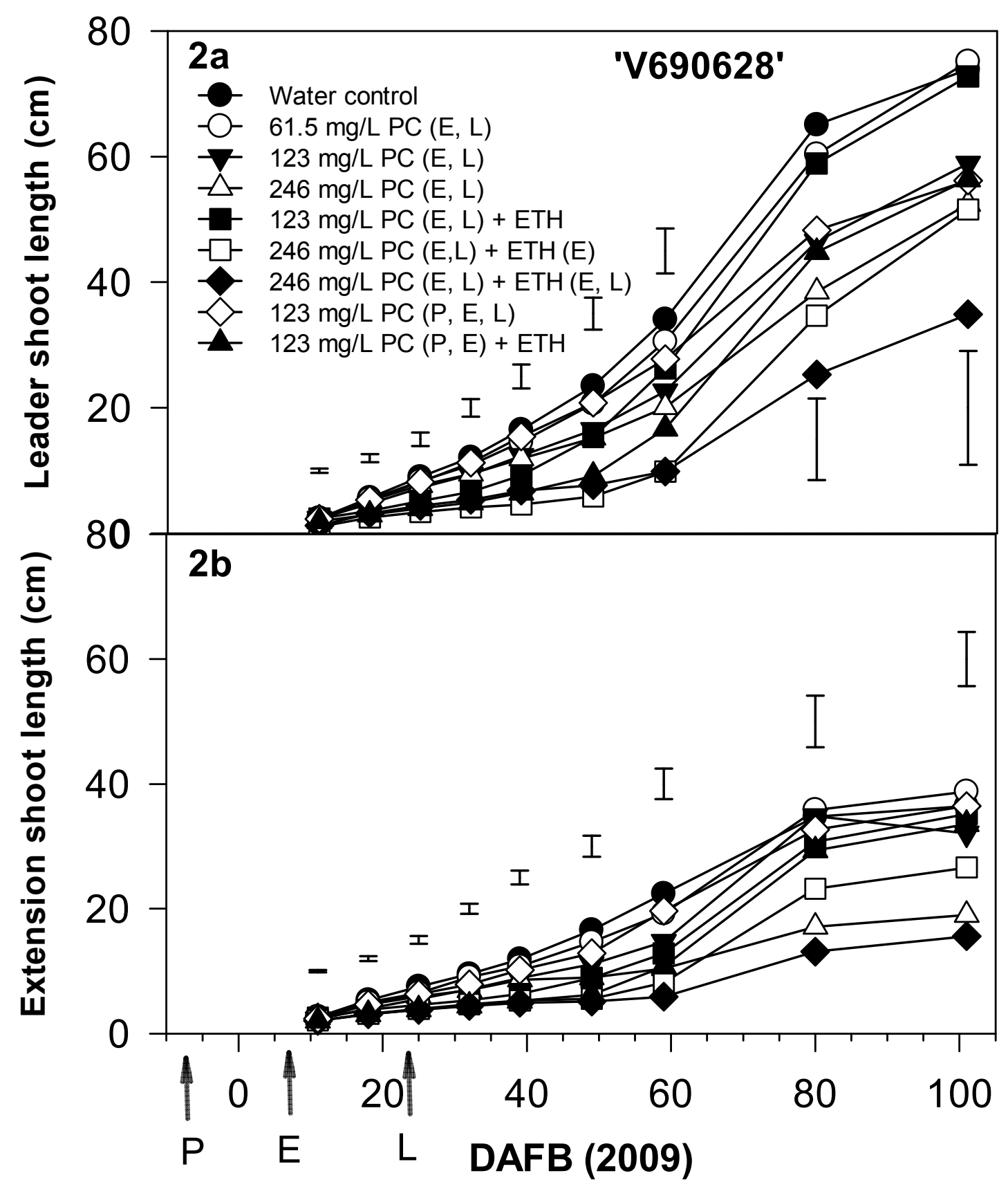

Figure 2. Primary leader (2a) and extension (2b) shoot growth of 8-yr-old 'V690628' sweet cherry trees over time as affected by different rates and application dates of prohexidione-calcium (PC) and Ethrel (ETH). Treatments: untreated control $(\mathbf{\bullet}), 61.5$ $\mathrm{mg} \mathrm{L}^{-1} \mathrm{PC}(\mathrm{O})$ applied $\mathrm{E}, \mathrm{L} ; 123 \mathrm{mg} \mathrm{L}^{-1} \mathrm{PC}(\boldsymbol{\nabla})$ applied E,L; $246 \mathrm{mg} \mathrm{L}^{-1} \mathrm{PC}$ applied E,L $(\triangle) ; 123 \mathrm{mg} \mathrm{L}^{-1} \mathrm{PC}$ applied E, L plus ETH applied $\mathrm{E}(\boldsymbol{\square}) ; 246 \mathrm{mg} \mathrm{L}^{-1} \mathrm{PC}$ applied $\mathrm{E}, \mathrm{L}$ plus

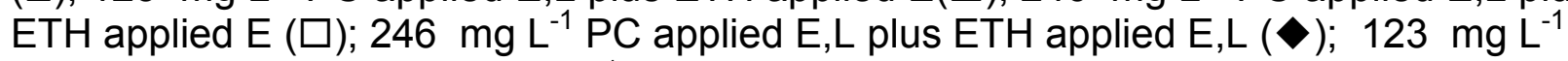
$\mathrm{PC}(\diamond)$ applied $\mathrm{P}, \mathrm{E}, \mathrm{L} ; 123 \mathrm{mg} \mathrm{L}^{-1} \mathrm{PC}(\mathbf{\Delta})$ applied $\mathrm{P}+\mathrm{E}$ plus ETH applied E.. All data are expressed as means and error bars represent the standard error of the means. Arrows indicate the application dates of PC [May 2, pre-bloom (P); May 15, early $(E)$; June 1 , late $(L)]$. 


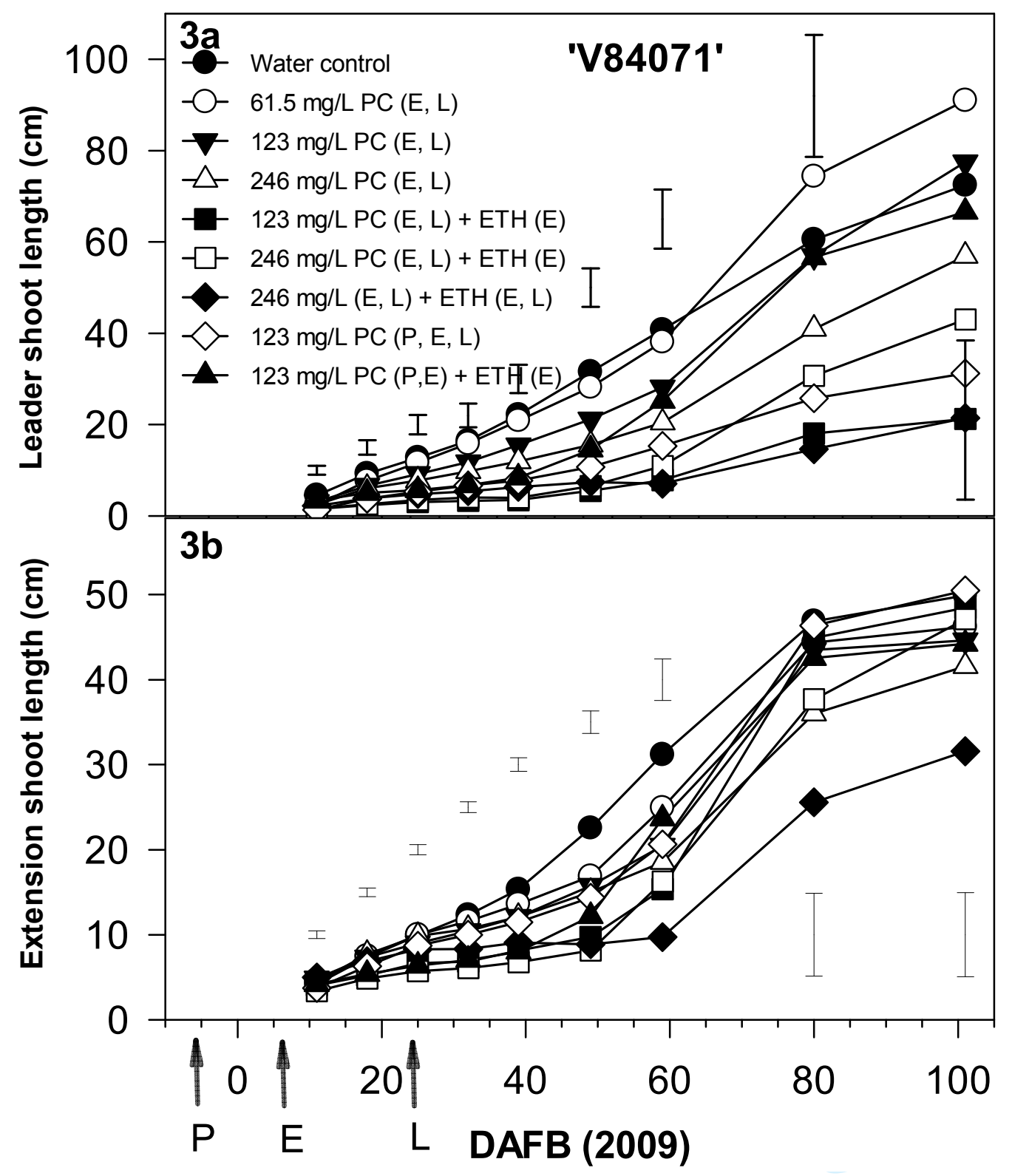

Figure 3. Primary leader (3a) and extension (3b) shoot growth of 8-yr-old 'V84071' sweet cherry trees over time as affected by different rates and application dates of prohexadione-calcium $(\mathrm{PC})$ and Ethrel $(\mathrm{ETH})$ combinations. Treatments: untreated control $(\bullet), 61.5 \mathrm{mg} \mathrm{L}^{-1} \mathrm{PC}(\mathrm{O})$ applied E, L ; $123 \mathrm{mg} \mathrm{L}^{-1} \mathrm{PC}(\boldsymbol{\nabla})$ applied E,L; $246 \mathrm{mg} \mathrm{L}^{-}$ ${ }^{1} \mathrm{PC}$ applied E,L $(\Delta) ; 123 \mathrm{mg} \mathrm{L}^{-1} \mathrm{PC}$ applied E,L plus ETH applied $\mathrm{E}(\boldsymbol{\square}) ; 246 \mathrm{mg} \mathrm{L}^{-1}$ PC applied E,L plus ETH applied E ( $\square) ; 246 \mathrm{mg} \mathrm{L}^{-1} P C$ applied E,L plus ETH applied $\mathrm{E}, \mathrm{L}(\diamond) ; 123 \mathrm{mg} \mathrm{L}^{-1} \mathrm{PC}$ applied $\mathrm{P}, \mathrm{E}, \mathrm{L}(\diamond) ; 123 \mathrm{mg} \mathrm{L}^{-1} \mathrm{PC}$ applied $\mathrm{P}+\mathrm{E}$ plus ETH applied $\mathrm{E}(\mathbf{\Delta})$. All data are expressed as means and error bars represent the standard error of the means. Arrows indicate the application dates of PC [May 2, pre-bloom (P); May 15 , early $(E)$; June 1 , late $(L)]$. 


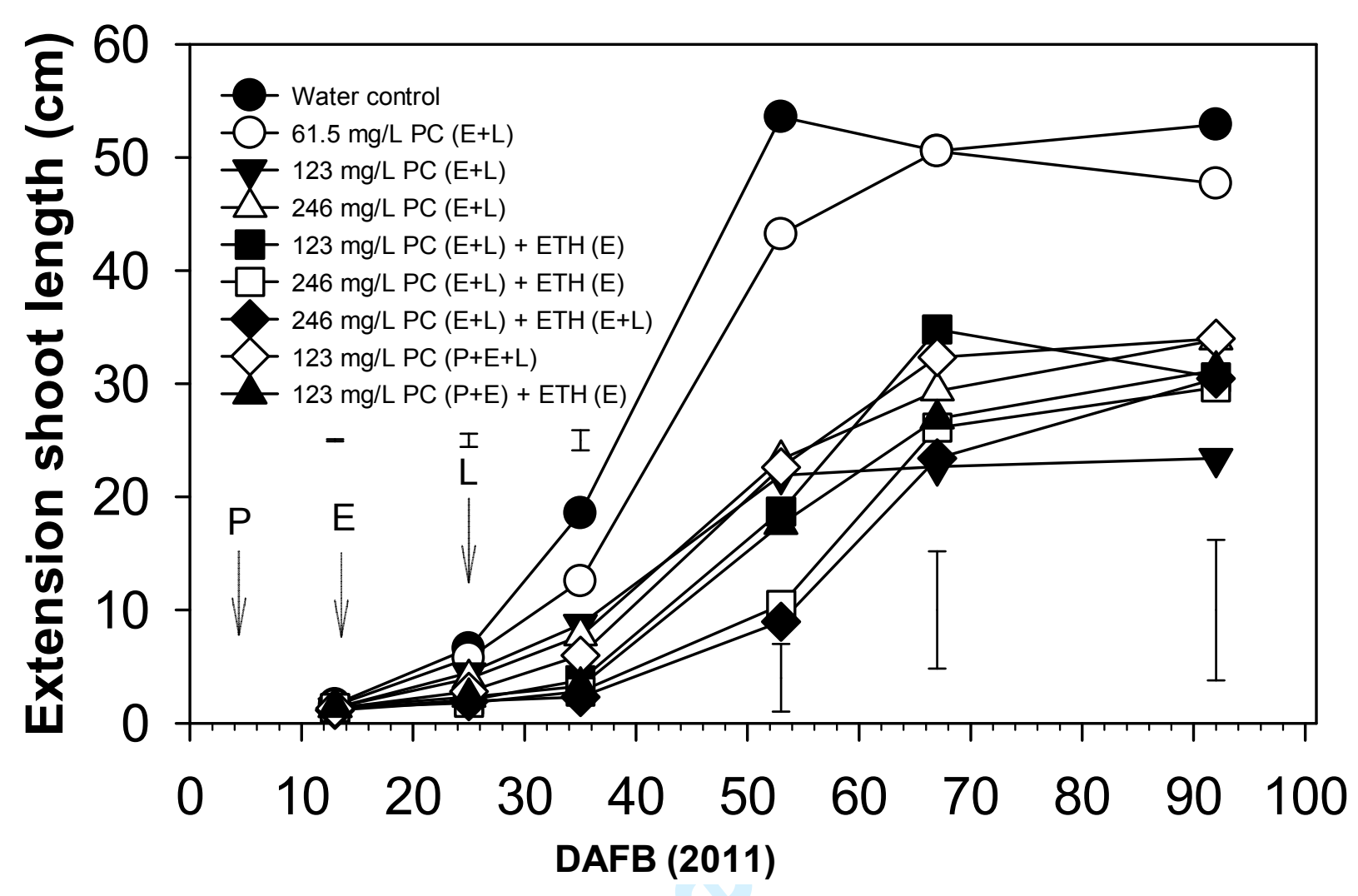

Figure 4. Extension shoot growth of 10-yr-old 'V690628'/G.6 sweet cherry trees over time as affected by different rates and application dates of prohexadione-calcium (PC). Treatments: untreated control $(\bullet), 61.5 \mathrm{mg} \mathrm{L}^{-1} \mathrm{PC}(\mathrm{O})$ applied $\mathrm{E}, \mathrm{L} ; 123 \mathrm{mg} \mathrm{L}^{-1} \mathrm{PC}(\boldsymbol{\nabla})$ applied E,L; $246 \mathrm{mg} \mathrm{L}^{-1} \mathrm{PC}$ applied $\mathrm{E}, \mathrm{L}(\Delta) ; 123 \mathrm{mg} \mathrm{L}^{-1} \mathrm{PC}$ applied $\mathrm{E}, \mathrm{L}$ plus Ethrel $(\mathrm{ETH})$ applied $\mathrm{E}(\boldsymbol{\square}) ; 246 \mathrm{mg} \mathrm{L}^{-1} \mathrm{PC}$ applied E, L plus ETH applied $\mathrm{E}(\square) ; 246 \mathrm{mg} \mathrm{L}^{-1} \mathrm{PC}$ applied E,L plus ETH applied E,L $(\diamond) ; 123 \mathrm{mg} \mathrm{L}^{-1} \mathrm{PC}(\diamond)$ applied $\mathrm{P}, \mathrm{E}, \mathrm{L} ; 123 \mathrm{mg} \mathrm{L}^{-1}$ $\mathrm{PC}(\boldsymbol{\Delta})$ applied $\mathrm{P}+\mathrm{E}$ plus ETH applied E. All data are expressed as means and error bars represent the standard error of the means. Arrows indicate the application dates of PC [May 12, pre-bloom (P); May 21, early (E); June 4, late (L)]. 


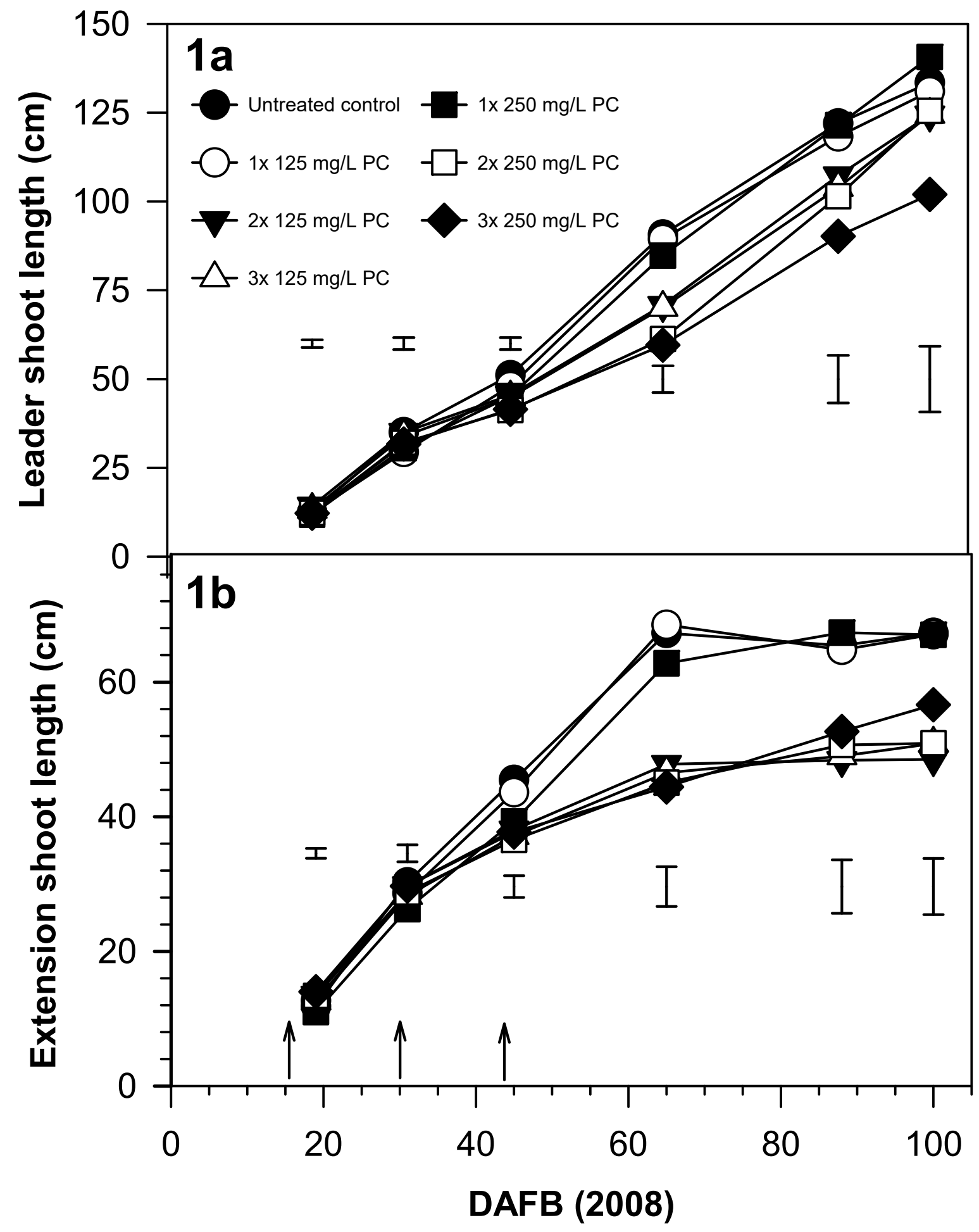




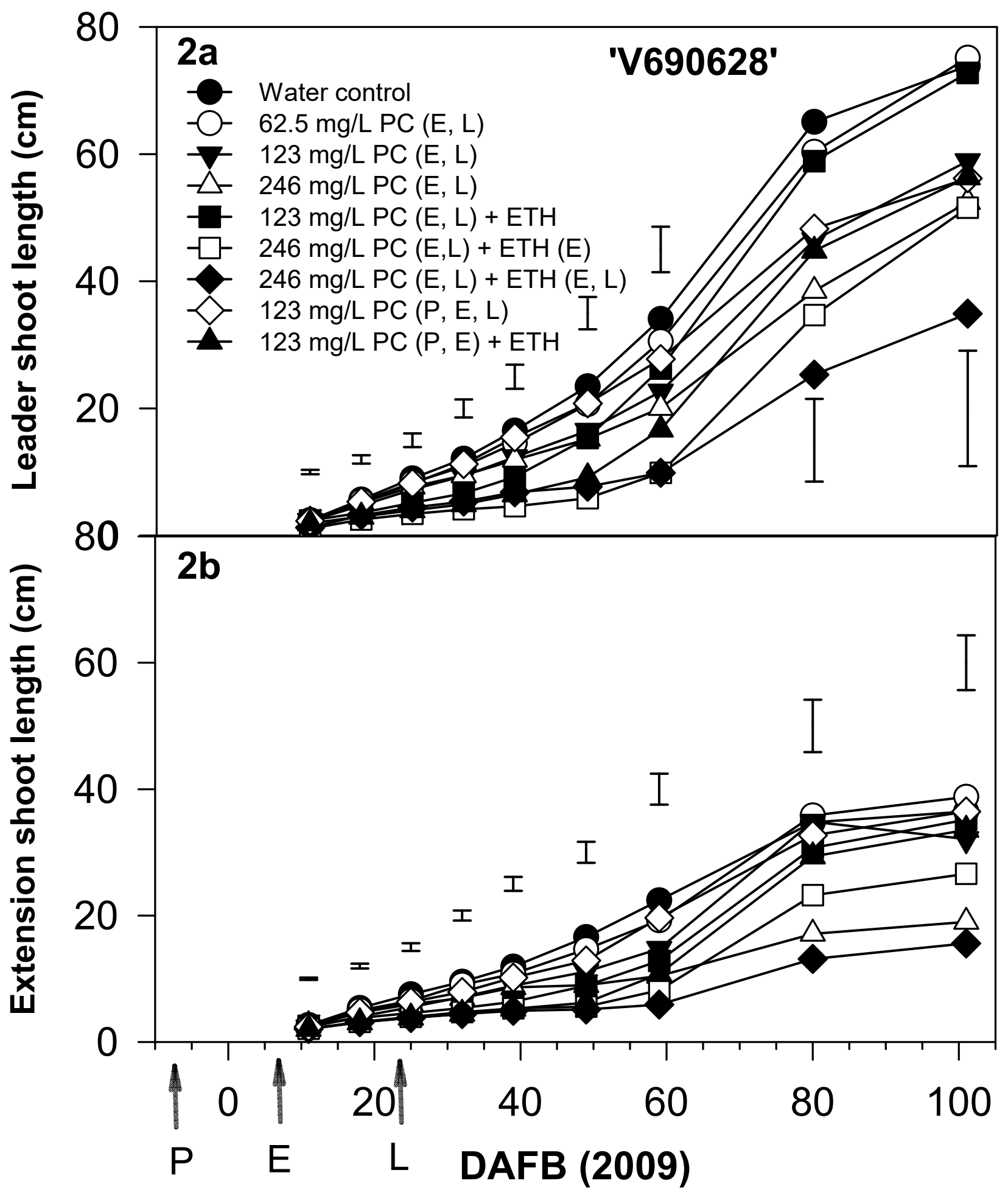




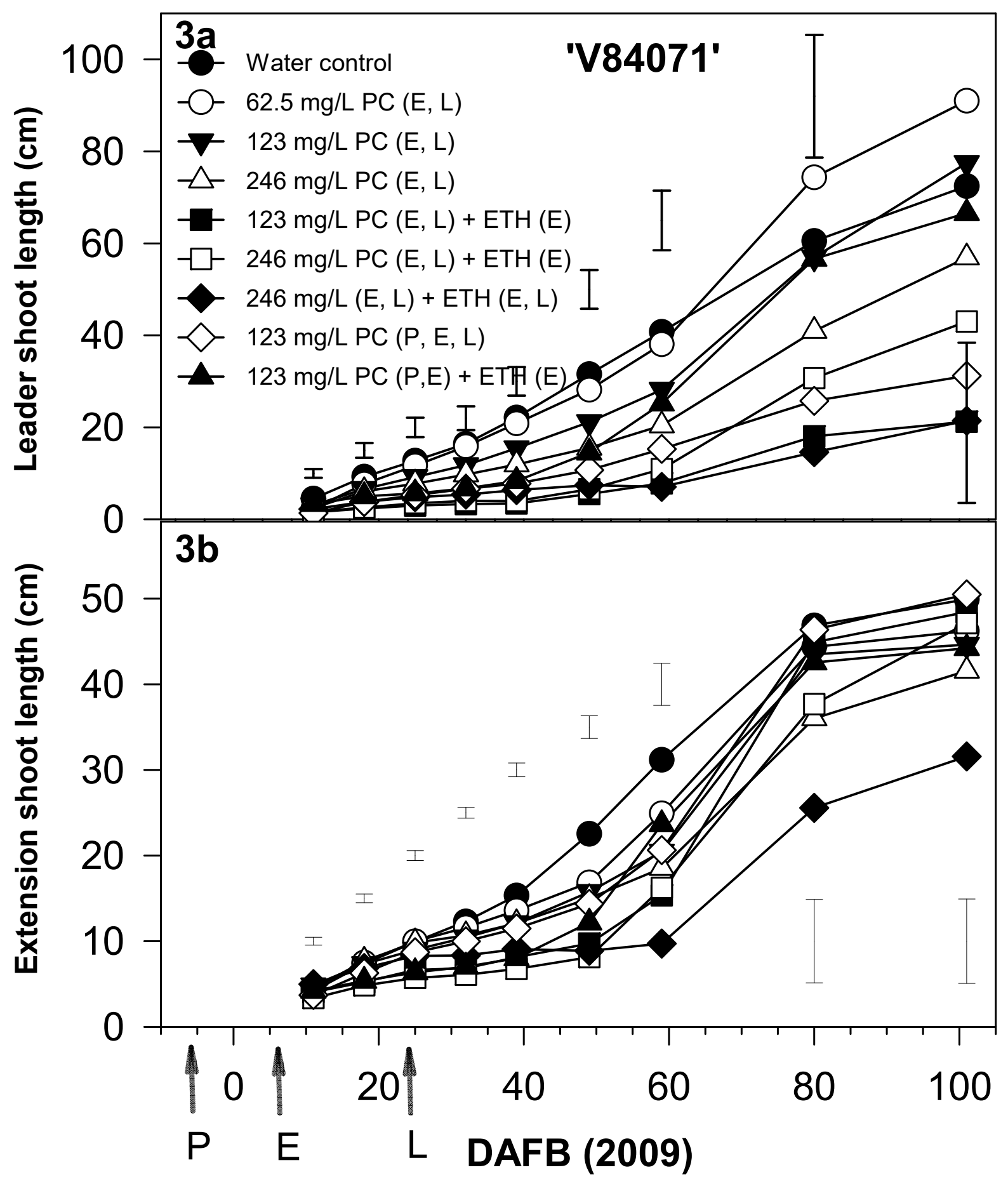




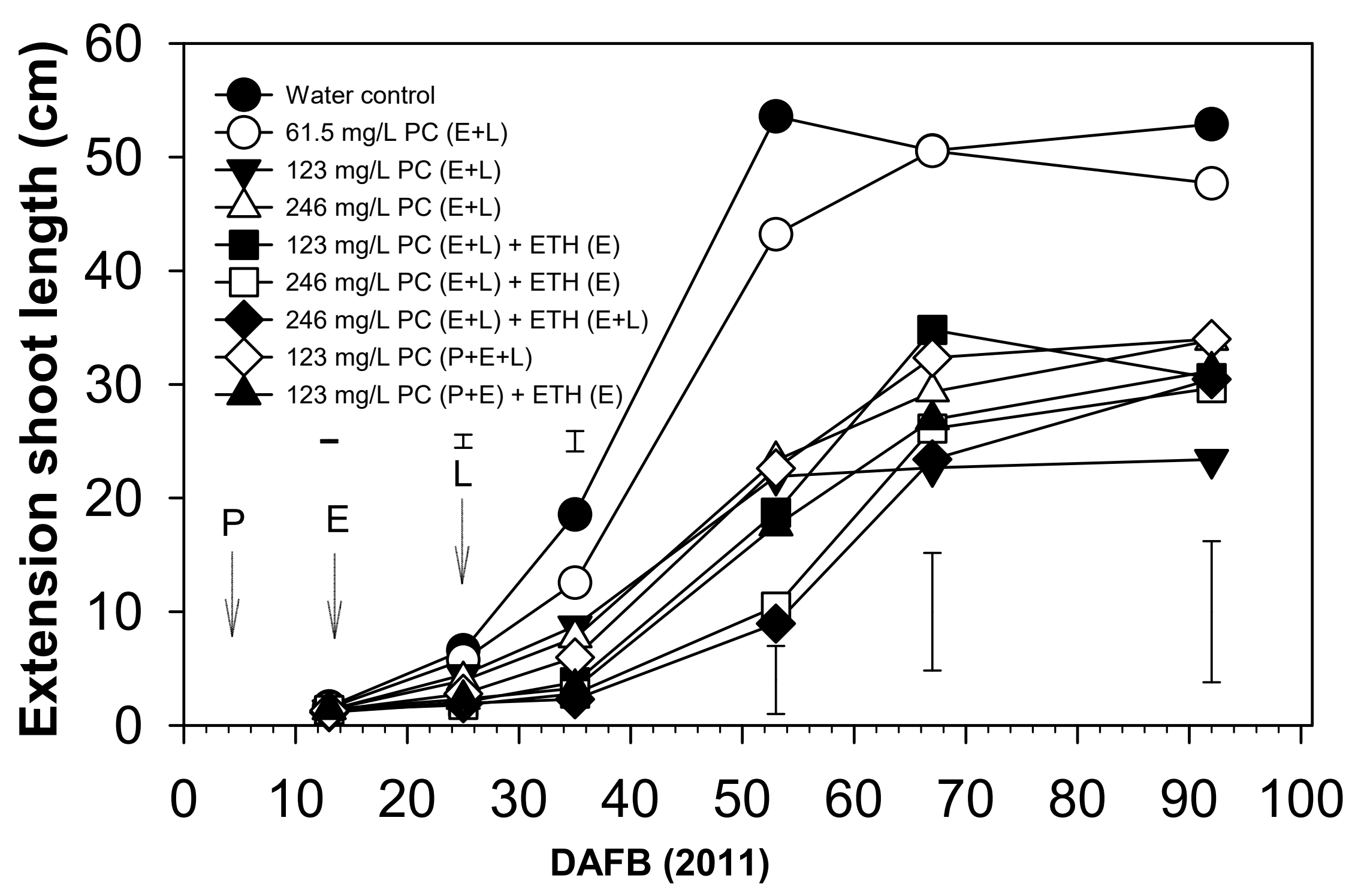

